\title{
Antibacterial activity of nutmeg (Myristica fragrans Houtt.) extract against foodborne pathogens on raw beef during chilled and frozen storage
}

\author{
${ }^{1,2}$ Ben Lagha, O.M., ${ }^{1}$ Zakaria, M.P., ${ }^{3}$ Ismail, I.S., ${ }^{1}$ Nor-Khaizura, M.A.R. and \\ $1,3^{*}$ Rukayadi, Y. \\ ${ }^{I}$ Department of Food Science, Faculty of Food Science and Technology, Universiti Putra Malaysia, 43400 \\ UPM Serdang, Selangor Darul Ehsan, Malaysia \\ ${ }^{2}$ Department of Food Science, Faculty of Agriculture, University of Tripoli, 13538, Tripoli, Libya \\ ${ }^{3}$ Laboratory of Natural Products, Institute of Bioscience, Universiti Putra Malaysia, 43400 UPM Serdang, \\ Selangor Darul Ehsan, Malaysia
}

\begin{abstract}
Article history:
Received: 4 August 2019 Received in revised form: 18 September 2019

Accepted: 20 September 2019

Available Online: 14 October 2019
\end{abstract}

Keywords:

Antibacterial activity,

Nutmeg extract,

Natural preservative

DOI:

https://doi.org/10.26656/fr.2017.4(2).280

\begin{abstract}
In recent years, demands for minimal processing and free-synthetic preservatives are increasing because of growing concern among consumers regarding the safety issues of additives. Nutmeg (Myristica fragrans Houtt.) has been used as a spice and traditional medicine in Asian countries. This study aimed to determine the antibacterial activity of nutmeg extract against foodborne pathogens on raw beef during storage. Nutmeg seeds were extracted using a maceration method with methanol as a solvent. The extract was assessed for antibacterial activity against a range of microorganisms using the disc diffusion assay, minimum inhibitory concentration and minimum bactericidal concentration. The effect of heat and different $\mathrm{pH}$ of the extract on its antibacterial activity was also conducted to evaluate the stability of the extract. The effects of the extract at different concentrations on the microbial population of the raw beef during chilled $\left(4.0 \pm 0.2^{\circ} \mathrm{C}\right)$ and frozen $\left(-18.0 \pm 0.2^{\circ} \mathrm{C}\right)$ storage for 21 days were then evaluated. The nutmeg extract exhibited antimicrobial activity against the range of microorganisms tested, which was stable at high temperature $\left(80.0 \pm 2.0^{\circ} \mathrm{C}\right)$ and in the $\mathrm{pH}$ range tested (3.0, 6.8 , and 11). Furthermore, the extract significantly inhibited microbial growth on raw beef stored for 21 days in chilled or frozen conditions, indicating that the nutmeg extract has the potential to be developed as a natural antimicrobial preservative in beef.
\end{abstract}

\section{Introduction}

Microbial activity by food spoilage bacteria is one of the primary causes of deterioration of many foods and is often responsible for food quality, spoilage, and economic loss. In addition, food industries have many safety concerns regarding particular foodborne pathogens, such as Salmonella spp, Escherichia coli, and Staphylococcus aureus, which are responsible for most foodborne diseases (Acheson, 2003). The problem of food preservation has become more complicated as new food products are frequently introduced on the market requiring long-term shelf-life protection from microbial spoilage (Patal and Kamble, 2011). Several preservation techniques have been used to improve beef freshness, including heat treatment, salting, and acidification (Davidson and Taylor, 2007). However, these techniques can cause deterioration in nutrient value and food safety (Annalisa et al., 2012). Furthermore, due to negative consumer perceptions of artificial preservatives, attention is shifting towards natural preservatives. Recently, interest has focused on the utilisation of plants that have the antimicrobial activity to control pathogens in foods. Consequently, alternative preservatives possessing antimicrobial activity with no harmful effects on human health are in high demand (Patal and Kamble, 2011).

Plant parts including leaves, flower, seed, stem, bark, root or whole plant have been used in foods since ancient times, not only as folk medicine, but also as flavouring agents and food preservatives (Dillon, 1994; Culter, 1995) due to their antimicrobial activity against specific pathogens (Erasto et al., 2004). Moreover, the plant part does not exhibit toxicity at consumed levels and are considered as GRAS (generally recognised as safe) substances (Souza et al., 2005). Nutmeg, Myristica fragrans Houtt., locally named as "pala" is an evergreen tree that produces drupe type fruits, belonging to the Myristicaceae family. Nutmeg is widely used as a spice in cooking and numerous traditional medicines (Dorman 
et al., 2000). Various studies have established the therapeutic value of $M$. fragrans; mace and seed of nutmeg possess antioxidant and antimicrobial effect (Ashish et al., 2013), thus nutmeg may be a potential natural preservative to inhibit the growth of pathogenic and spoilage microorganisms. There are several ways to use natural preservatives in the food, they can be directly added to the product formulation such as coating, spraying or dipping on the surface of the food (Velasco and Williams, 2011).

The present study was conducted to determine the antibacterial activity of $M$. fragrans Houtt. extract against selected foodborne pathogens on raw beef during storage at $4^{\circ} \mathrm{C}$ (chiller) and $-18^{\circ} \mathrm{C}$ (freezer). It is expected that the study findings will be used as primary evidence of the potential of nutmeg extract to be used as natural preservative to replace chemical preservatives.

\section{Materials and methods}

\subsection{Nutmeg extraction}

Nutmegs were collected at Taman Pertanian, Bukit Ekspo, UPM, Selangor, Malaysia and dried in the oven at $50^{\circ} \mathrm{C}$ for three days. The dried nutmeg $(100 \mathrm{~g})$ was ground and extracted with $400 \mathrm{~mL}$ of $99.8 \%(\mathrm{w} / \mathrm{v})$ absolute methanol (Sigma-Aldrich, Saint Louis, MO, USA) for seven days at room temperature according to the method of Rukayadi et al. (2008) with some modification. After seven days, the plant material was filtered using Whatman No. 1 filter paper (Whatman International Ltd., Middlesex, England) and concentrated using a rotary vacuum evaporator (Heidolph VV2011, Schwabach, Germany) at $50^{\circ} \mathrm{C}$ with a speed of $150 \mathrm{rpm}$ for 3-4 hrs. The temperature was increased to $80^{\circ} \mathrm{C}$ for 2 $\times 30 \mathrm{~s}$ to obtain methanol-free extracts. The active compounds in the extract were unaffected by this temperature (Rukayadi et al., 2008). The crude extract was then stored at $4^{\circ} \mathrm{C}$.

\subsection{Antibacterial activity of Myristica fragrans Houtt. extract against foodborne pathogens}

\subsubsection{Preparation of nutmeg extract and chlorhexidine solutions}

A $10 \%(\mathrm{w} / \mathrm{v})$ extract of $M$. fragrans Houtt. was prepared by dissolving $100 \mathrm{mg}$ of crude extract in $1 \mathrm{~mL}$ of dimethyl sulfoxide (DMSO) $(99.9 \%)$ ( $\mathrm{R}$ and $\mathrm{M}$ Marketing, Essex, UK). This was further diluted in 1:10 sterile distilled water to produce $1 \%(\mathrm{w} / \mathrm{v})$ extract, with a final DMSO concentration of $10 \%$, which does not kill bacteria (Rukayadi et al., 2008). A $1 \%(\mathrm{w} / \mathrm{v})$ solution of chlorhexidine (Sigma, St. Louis, MO, USA) was prepared by dissolving $1 \mathrm{mg}$ in $1 \mathrm{~mL}$ of double-distilled water $\left(\mathrm{ddH}_{2} \mathrm{O}\right)$.

\subsubsection{Bacterial strains}

B. cereus ATCC33019, B. subtilis ATCC6633, E. coli ATCC25922, K. pneumoniae ATCC13733, L. monocytogenes ATCC19112, P. aeruginosa ATCC9027 and P. mirabilis ATCC21100 were obtained from the American Type Culture Collection (Rockville, Maryland, USA). S. aureus KCCM12255 was obtained from the Korean Culture Centre of Microorganisms (Seoul, South Korea). All bacteria were cultured and maintained statistically in nutrient agar (NA: Difco, Sparks, Maryland, USA).

\subsubsection{Disc diffusion assay}

M. fragrans Houtt. extract was tested for antibacterial activity using a standard paper disc diffusion assay (CLSI, 2012). Briefly, $100 \mu \mathrm{L}$ of microbial inoculum was spread on Mueller Hinton Agar (MHA: Difco, Franklin Lakes, NJ, USA) using a sterile cotton swab. Sterile paper discs $(6 \mathrm{~mm})$ (Schleicher and Schuell, Dassel, Germany) were impregnated with $10 \mu \mathrm{L}$ of $1 \%$ of $M$. fragrans Houtt. extract, with $1 \%$ chlorhexidine included as a positive control and $10 \%$ DMSO as a negative control. The plates were incubated at $37^{\circ} \mathrm{C}$ for $24 \mathrm{hrs}$ and the inhibition zones surrounding the paper discs were measured. The test was performed in triplicate to verify the results.

\subsubsection{Minimum inhibitory concentration (MIC) and minimum bactericidal concentration (MBC)}

Determination of MIC and MBC values was performed using a method described in the CLSI (2012). MIC was conducted in 96-well round-shaped bottom microtiter plate (BrandonTM, Malaysia), using two-fold standard broth microdilution methods with an inoculum of approximately $10^{6} \mathrm{CFU} / \mathrm{mL}$. Nutmeg extract or positive control $1 \%$ chlorhexidine were two-fold diluted in the respective medium containing inoculum. Column 12 of the microtiter plate contained the highest concentration of extract $(5 \mathrm{mg} / \mathrm{mL})$, while column 3 contained the lowest concentration of extract $(0.0097$ $\mathrm{mg} / \mathrm{mL}$ ). Column 1 served as negative growth control (only medium, no inoculum, and no antimicrobial agent), while column 2 served as positive growth control for all samples (only medium and inoculum or antimicrobial agent-free well). The plates were then incubated at $37^{\circ} \mathrm{C}$ for $24 \mathrm{hrs}$. The MIC was defined as the lowest concentration of antimicrobial agent that resulted in the complete inhibition of visible growth (CLSI, 2012), that is, the well with no visible growth compared to the positive and negative growth wells.

The MBC was defined as the lowest concentration of antimicrobial agent at which no growth occurred on the 
agar plates and was determined by sub-culturing the suspension $(10 \mu \mathrm{L})$ from each well on MHA. The plates were then incubated at $37^{\circ} \mathrm{C}$ for $24 \mathrm{hrs}$ or until growth was observed in the positive growth control. The lowest concentration that did not produce visible growth after the incubation period was considered as the MBC (Andrews, 2001).

\subsubsection{Stability of Myristica fragrans Houtt. extract to heat and different $\mathrm{pH}$}

The stability of the extract to heat and different $\mathrm{pH}$ was assessed by the method reported by Lee et al. (2008). Briefly, $1 \%(\mathrm{w} / \mathrm{v})$ crude extract was heated to $80 \pm 2^{\circ} \mathrm{C}$ for 30 mins using a water bath heater, then cooled. The original $\mathrm{pH}$ of the extract was $6.8 \pm 0.2$, so the $\mathrm{pH}$ was adjusted to $3.0 \pm 0.2$ and $11.0 \pm 0.2$ using $1 \mathrm{M}$ $\mathrm{HCl}$ and $\mathrm{NaOH}$, respectively. The antibacterial activity of all treated extracts was then assessed by the disc diffusion assay as described in section 2.2.3.

\subsection{Effect of Myristica fragrans Houtt. extract on} microbial growth on raw beef during chilled and frozen storage

The crude nutmeg extract was diluted using sterile deionised water (DIW) (B Braun Medical Industries, Penang, Malaysia) to prepare concentrations of $0.00 \%$ (only DIW), $0.25 \%, 0.50 \%, 1.25 \%, 2.50 \%$ and $5.00 \%$ $(w / v)$. Beef samples were purchased at Pusat Sembelihan Lembu Daging, Shah Alam, Selangor and transported to the Food Science Laboratory, UPM on ice within 40 mins. The beef was cut into $2.5 \times 2.5 \times 2.0 \mathrm{~cm}$ samples, weighing an average of $3.0 \pm 0.1 \mathrm{~g}$, before randomly divided into three groups: control group, chilled group and frozen group. The beef samples were then soaked in $10 \mathrm{~mL}$ of different concentrations for $15 \mathrm{mins}$, before packaged with overwrapped trays with stretched polyethylene permeable film (Polypack Enterprises, Selangor, Malaysia) and stored in the chiller $\left(4.0 \pm 0.2^{\circ} \mathrm{C}\right)$ for 21 days and freezer $\left(-18.0 \pm 0.2^{\circ} \mathrm{C}\right)$ for 14 days. The experiment was repeated two times with duplicates $(\mathrm{n}=$ $2 \times 2)$.

On day zero, $1^{\text {st }}, 4^{\text {th }}, 7^{\text {th }}, 10^{\text {th }}, 14^{\text {th }}$ and $21^{\text {st }}$, the microbial populations in the beef samples were evaluated by homogenising a sample using a stomacher. Serial dilutions using $10 \mathrm{~mL} \mathrm{M}$ phosphate buffer were prepared, of which, $0.02 \mathrm{~mL}$ was spread on plate count agar (PCA: Difco, Spark, MD, USA), chromocult coliform agar (Merck, Darmstadt, Germany), Listeria selective agar (Merck, Darmstadt, Germany) and E. coli chromagar (Merck, Darmstadt, Germany). The petri dishes were incubated at $37^{\circ} \mathrm{C}$ for $24 \mathrm{hrr}$, then plate counts were performed to calculate the logarithm numbers of colony-forming unit per gram $\left(\log _{10} \mathrm{CFU} / \mathrm{g}\right)$ of samples.

\subsection{Statistical analysis}

Data were analysed using MINITAB v16.1 Windows (Minitab Inc) by the analysis of variance (ANOVA), one -way, unstacked, where Tukey's test was used to determine the significance of difference $(P=0.05)$ between treatments.

\section{Results and discussion}

3.1 Antibacterial activity of the Myristica fragrans Houtt. extract and its stability

M. fragrans Houtt. extract inhibited the growth of the eight foodborne pathogens tested as shown by the inhibition zones presented in Table 1. The disc diffusion assay is a semi-quantitative analysis and according to Gangoué-Piéboji et al. (2009), some active compounds may be trapped in the disc pores and unable to pass through into the inoculated media, hence the results do not truly represent their complete antimicrobial activity. Furthermore, the inability of hydrophobic compounds to diffuse into the media agar could provide non-accurate results (Othman et al., 2011). Nonetheless, as a screening technique, the disc diffusion assay allows the detection of active compounds in plant extracts, as the size of the inhibition zone indicates the degree of antibacterial activity. Hence, M. fragrans Houtt. extract was more effective against $B$. cereus, B. subtilis, E. coli, K. pneumoniae, $P$. mirabilis and $S$. aureus strains, being less effective against the Gram-negative $P$. aeruginosa. Generally, in gram negative bacteria, their outer membranes serve as permeability barrier which allow only small hydrophilic molecules to pass through into the cell, restricting their rate of penetration for certain antimicrobial compounds and excluding larger molecules. Furthermore, they possess multidrug-resistant pumps which also exclude some antibacterial compounds; thus, they are more tolerant to exposure to foreign compounds (Lambert, 2002).

The MICs of nutmeg extract are presented in Table 1. The extract exhibited satisfactory MBCs of $0.31 \mathrm{mg} /$ $\mathrm{mL}, 1.25 \mathrm{mg} / \mathrm{mL}, 0.63 \mathrm{mg} / \mathrm{mL}, 0.63 \mathrm{mg} / \mathrm{mL}, 1.25 \mathrm{mg} /$ $\mathrm{mL}, 2.50 \mathrm{mg} / \mathrm{mL}, 0.63 \mathrm{mg} / \mathrm{mL}$ and $0.63 \mathrm{mg} / \mathrm{mL}$ for $B$. cereus, B. subtilis, E. coli, $K$. pneumoniae, $L$. monocytogenes, $P$. aeruginosa, $P$. mirabilis and $S$. aureus, respectively. Taken together, these results show that the extract was bacteriostatic to $B$. cereus, $B$. subtilis, E. coli, $K$. pneumoniae, $P$. aeruginosa and $P$. mirabilis and had a bactericidal effect on $L$. monocytogenes and $S$. aureus. The nutmeg extract was most effective against $B$. cereus, as evidenced by the largest inhibition zone $(12.00 \pm 0.00 \mathrm{~mm})$, and lowest MIC $(0.16 \mathrm{mg} / \mathrm{mL})$ and $\mathrm{MBC}(0.31 \mathrm{mg} / \mathrm{mL})$ values. 
Table 1. Inhibition zone, MICs and MBCs of M. fragrans Houtt. extract against foodborne pathogens without treatment, after heat and $\mathrm{pH}$ treatments

\begin{tabular}{|c|c|c|c|c|c|c|c|}
\hline \multirow[b]{2}{*}{ Bacterial strain } & \multirow{2}{*}{$\begin{array}{c}\mathrm{MIC} \\
(\mathrm{mg} / \mathrm{mL})\end{array}$} & \multirow{2}{*}{$\begin{array}{c}\mathrm{MBC} \\
(\mathrm{mg} / \mathrm{mL})\end{array}$} & \multirow{2}{*}{$\begin{array}{c}\text { Inhibition zone }(\mathrm{mm}) \\
\text { of } 1 \% \text { extract without } \\
\text { treatment }\end{array}$} & \multirow{2}{*}{$\begin{array}{c}\text { Inhibition zone }(\mathrm{mm}) \\
\text { of } 1 \% \text { extract after } \\
\text { heating at } 80.0 \pm 2.0^{\circ} \mathrm{C}\end{array}$} & \multicolumn{3}{|c|}{ Inhibition zone $(\mathrm{mm})$ of $1 \%$ extract at $\mathrm{pH}$} \\
\hline & & & & & 3 & 6.8 & 11 \\
\hline $\begin{array}{l}\text { B. cereus } \\
\text { ATCC } 33019\end{array}$ & 0.16 & 0.31 & $12.00 \pm 0.00$ & $10.00 \pm 0.00$ & $12.00 \pm 0.00$ & $12.00 \pm 0.00$ & $12.00 \pm 0.00$ \\
\hline $\begin{array}{l}\text { B. subtilis } \\
\text { ATCC6633 }\end{array}$ & 0.63 & 1.25 & $11.33 \pm 0.67$ & $11.33 \pm 0.67$ & $11.00 \pm 0.00$ & $11.33 \pm 0.67$ & $10.00 \pm 0.00$ \\
\hline $\begin{array}{l}\text { E. coli } \\
\text { ATCC } 25922\end{array}$ & 0.31 & 0.63 & $10.67 \pm 0.33$ & $8.67 \pm 0.33$ & $11.33 \pm 0.67$ & $10.67 \pm 0.33$ & $9.67 \pm 0.33$ \\
\hline $\begin{array}{l}\text { K. pneumoniae } \\
\text { ATCC } 13733\end{array}$ & 0.31 & 0.63 & $11.00 \pm 0.00$ & $10.00 \pm 0.00$ & $11.00 \pm 0.00$ & $11.00 \pm 0.00$ & $10.33 \pm 0.67$ \\
\hline $\begin{array}{l}\text { L. monocytogenes } \\
\text { ATCC } 19112\end{array}$ & 1.25 & 1.25 & $9.50 \pm 0.50$ & $8.00 \pm 0.00$ & $9.00 \pm 0.00$ & $9.50 \pm 0.50$ & $8.00 \pm 0.00$ \\
\hline $\begin{array}{l}P . \text { aeruginosa } \\
\text { ATCC } 21100\end{array}$ & 1.25 & 2.5 & $8.00 \pm 0.00$ & $7.00 \pm 0.00$ & $8.00 \pm 8.00$ & $8.00 \pm 0.00$ & $7.50 \pm 0.50$ \\
\hline $\begin{array}{l}\text { P. mirabilis } \\
\text { ATCC } 9027\end{array}$ & 0.31 & 0.63 & $10.00 \pm 0.00$ & $10.00 \pm 0.00$ & $10.33 \pm 0.67$ & $10.00 \pm 0.00$ & $8.67 \pm 0.33$ \\
\hline $\begin{array}{l}\text { S. aureus } \\
\text { KCCM12255 }\end{array}$ & 0.63 & 0.63 & $11.33 \pm 0.67$ & $11.00 \pm 0.00$ & $10.00 \pm 0.00$ & $11.33 \pm 0.67$ & $10.33 \pm 0.67$ \\
\hline
\end{tabular}

These results agree with previous studies (Bin et al., 2007; El Malti et al., 2008; Ababutain, 2011), that nutmeg extract displayed antibacterial activity against a range of gram positive and Gram-negative bacteria including different serotypes of E. coli, Salmonella spp., L. monocytogenes, and Aeromonas hydrophila.

The stability of the extract was tested at three different $\mathrm{pH}(3.0,6.8$ and 11.0) and a high cooking temperature $\left(80.0 \pm 2.0^{\circ} \mathrm{C}\right)$ and the results are shown in Table 1 column 5, 6, 7 and 8 . The antimicrobial activity of the nutmeg extract was heat and $\mathrm{pH}$ stable, as there were no significant differences in the inhibition zones between the different conditions tested.

Numerous active compounds have been isolated from nutmeg seed, such as $\beta$-pinene, $\alpha$-pinene, sabinene, safrole, terpinene-t-ol, myristicin, $\alpha$-terpineol, $\alpha$ terpinene (Dorman et al., 2000; Chatterjee et al., 2007), eugenol, isoeugenol (Janssens et al., 1990), lignans (diarylbutane, aryltetraline) (Kwon et al., 2008), macelignan (Chung et al., 2006), which may be responsible for the antimicrobial effects. Previously, $\beta$ pinene, isolated from the M. fragrans Houtt, was shown to possess antioxidant and antimicrobial effects (Takikawa et al., 2002). These compounds which are responsible for antibacterial activity are stable to the change of temperature and $\mathrm{pH}$.

\subsection{Effect of Myristica fragrans Houtt. extract on microbial population in raw beef}

The effects of different concentrations of nutmeg extract on the microbial population including total plate count (TPC), coliform, E. coli and L. monocytogenes of raw beef in two storage conditions $4.0 \pm 0.2^{\circ} \mathrm{C}$ and $18.0 \pm 0.2^{\circ} \mathrm{C}$ were evaluated and the results are presented in Figure 1 to Figure 4. Typically, during 21 days of storage at $4^{\circ} \mathrm{C}$, beef samples are spoilt, producing unpleasant by the $13^{\text {th }}$ day. The North American meat industry recommends $2^{\circ} \mathrm{C}$ as the appropriate temperature for meat storage, nonetheless, even if $2^{\circ} \mathrm{C}$ is maintained, there is still a probability of $50 \%$ product loss (Jeremiah and Gibson, 2001).

The effect of nutmeg extract on the TPC of beef during storage at $4^{\circ} \mathrm{C}$ is presented in Figure 1a, showing that the number of TPC increased at low extract concentrations $(0.00 \%, 0.25 \%$ and $0.65 \%)$ as conditions were still favourable for microbial growth (Tan and Chen, 2005). In contrast, there were significant reduction of TPC at higher extract concentrations $(1.25 \%, 2.50 \%$ and $5.00 \%$ ) from $5.02 \log _{10} \mathrm{CFU} / \mathrm{g}$ to $4.00 \log _{10} \mathrm{CFU} / \mathrm{g}$, $3.70 \log _{10} \mathrm{CFU} / \mathrm{g}$ and $3.42 \log _{10} \mathrm{CFU} / \mathrm{g}$, respectively. The initial number of TPC for freezer temperature ($18.0 \pm 0.2^{\circ} \mathrm{C}$ ) was $5.11 \log _{10} \mathrm{CFU} / \mathrm{g}$ as shown in Figure $1 \mathrm{~b}$. The numbers of TPC at all concentrations were relatively constant, with no significant differences in TPC until the $4^{\text {th }}$ day. However, from $5^{\text {th }}$ day onwards, the TPC reduced significantly from 5.11 to $4.11,3.92$, 3.59 and 3.03 with concentrations of $0.25 \%, 0.65 \%$, $1.25 \%, 2.50 \%$ and $5.00 \%$, respectively (Figure $1 \mathrm{~b}$ ), suggesting that the extract can reduce the survival of TPC during freezer temperature storage.

The initial number of coliform at chiller storage temperature $\left(4.0 \pm 0.2^{\circ} \mathrm{C}\right)$ was $3.08 \log _{10} \mathrm{CFU} / \mathrm{g}$, which increased in the control sample, $0.00 \%$ and $0.25 \%$ extract conditions by the $14^{\text {th }}$ day (Figure 2 a). This low antimicrobial activity may be due to the formation of protective biofilms on the meat through excretion of extracellular polysaccharides by coliform (Doyle, 2005). Hence, the presence of biofilms on different beef may cause the non-uniform survival of the microbial and bacterial load during storage. At frozen storage temperature $\left(-18.0 \pm 0.2^{\circ} \mathrm{C}\right)$, the initial coliform count was $3.12 \log _{10} \mathrm{CFU} / \mathrm{g}$ (Figure 2b). After treatment with 
(a)

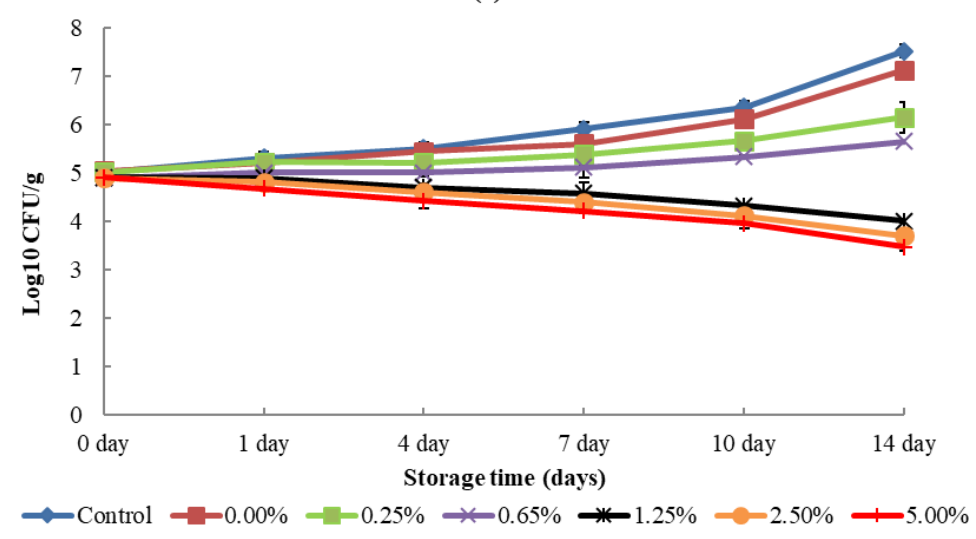

(b)

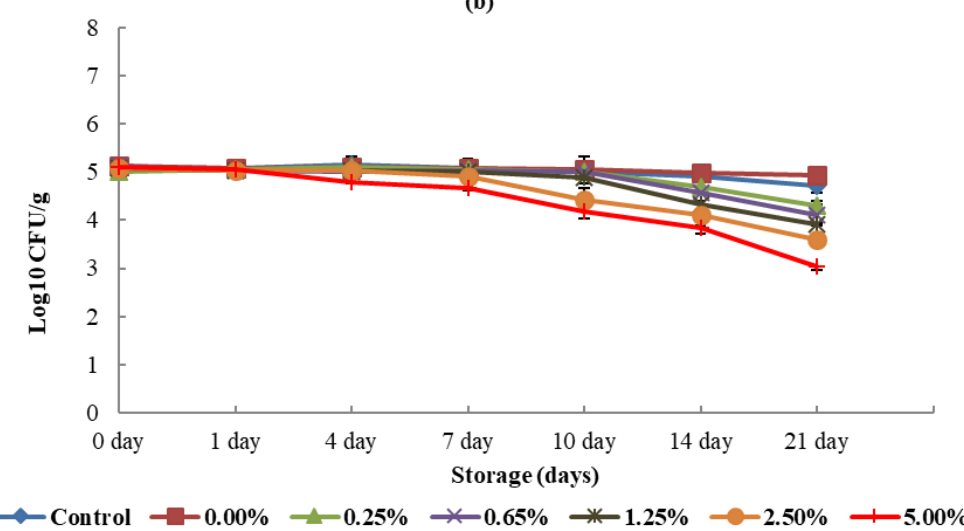

Figure 1. Effect of $M$. fragrans Houtt. extract treatment at concentration of $0.00 \%$ (DW, distilled water), $0.25 \%, 0.65 \%, 1.25 \%$, $2.50 \%$ and $5.00 \%$ on the total plate count (TPC) of beef during storage at $4 \pm 2{ }^{\circ} \mathrm{C}$ (a) and $-18 \pm 2{ }^{\circ} \mathrm{C}$ (b). Control was untreated raw beef sample.

(a)

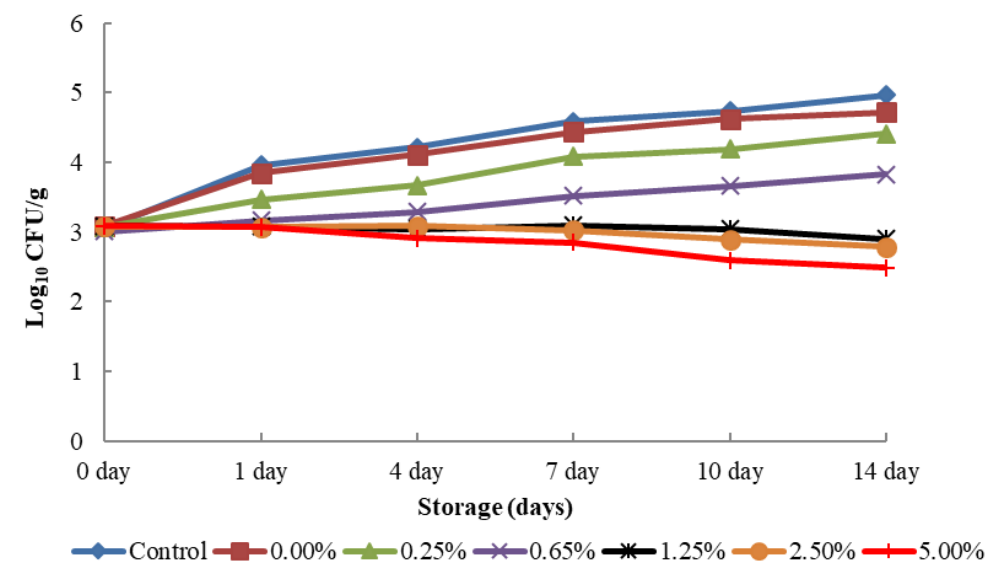

(b)

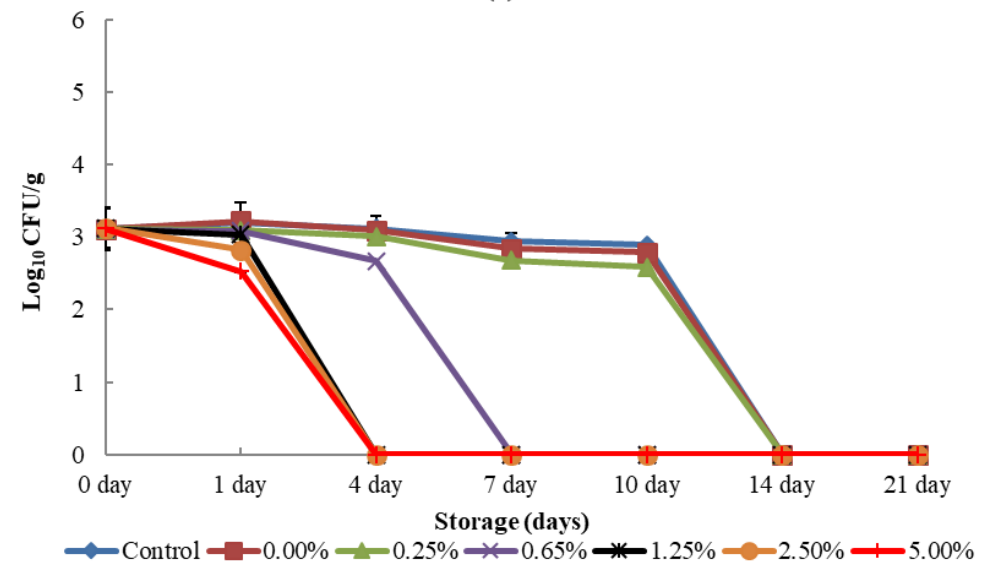

Figure 2. Effect of M. fragrans Houtt. extract treatment at concentration of $0.00 \%$ (DW, distilled water), $0.25 \%, 0.65 \%$, $1.25 \%$, $2.50 \%$ and $5.00 \%$ on coliform on beef during storage at $4 \pm 2{ }^{\circ} \mathrm{C}$ (a) and $-18 \pm 2^{\circ} \mathrm{C}$ (b). Control was untreated raw beef sample. 

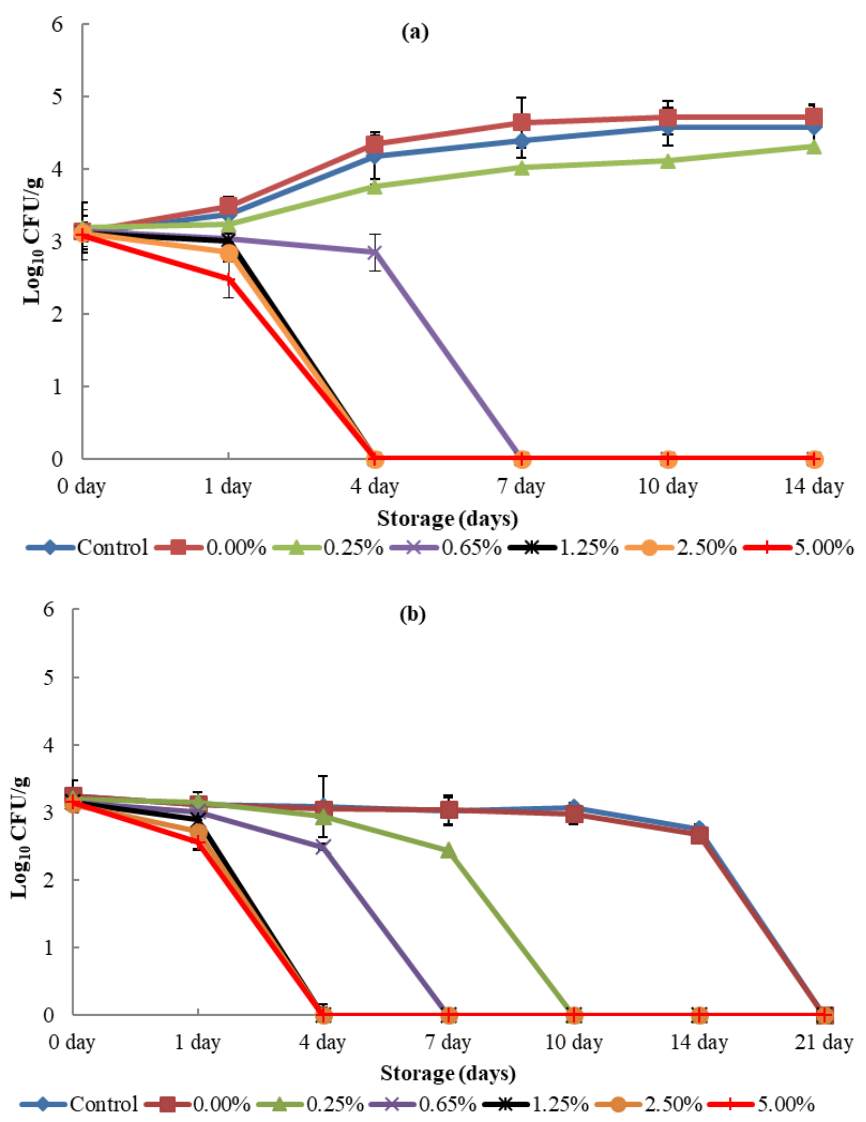

Figure 3. Effect of $M$. fragrans Houtt. extract treatment with concentration of $0.00 \%$ (DW, distilled water), $0.25 \%, 0.65 \%$, $1.25 \%, 2.50 \%$ and $5.00 \%$ on $E$. coli on beef during storage at $4 \pm 2{ }^{\circ} \mathrm{C}$ (a) and $-18 \pm 2{ }^{\circ} \mathrm{C}$ (b). Control was untreated raw beef sample.

(a)

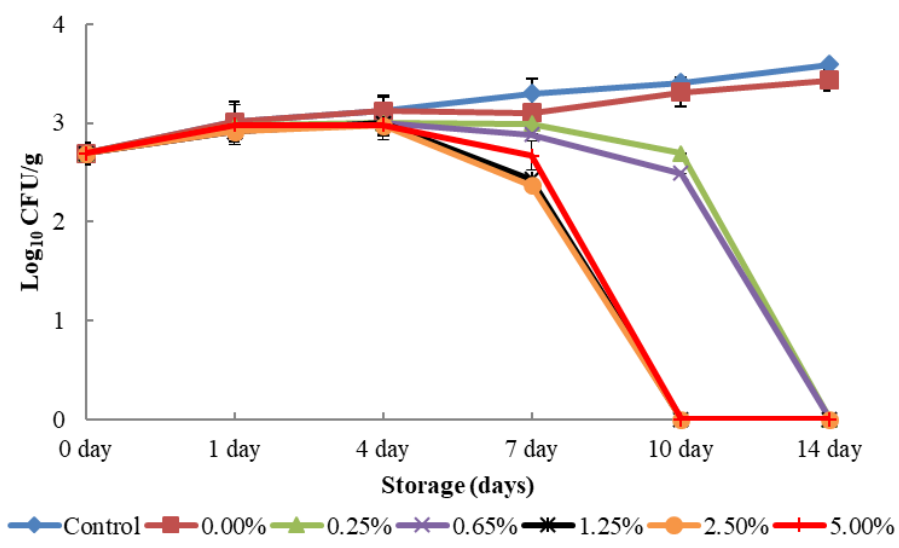

(b)

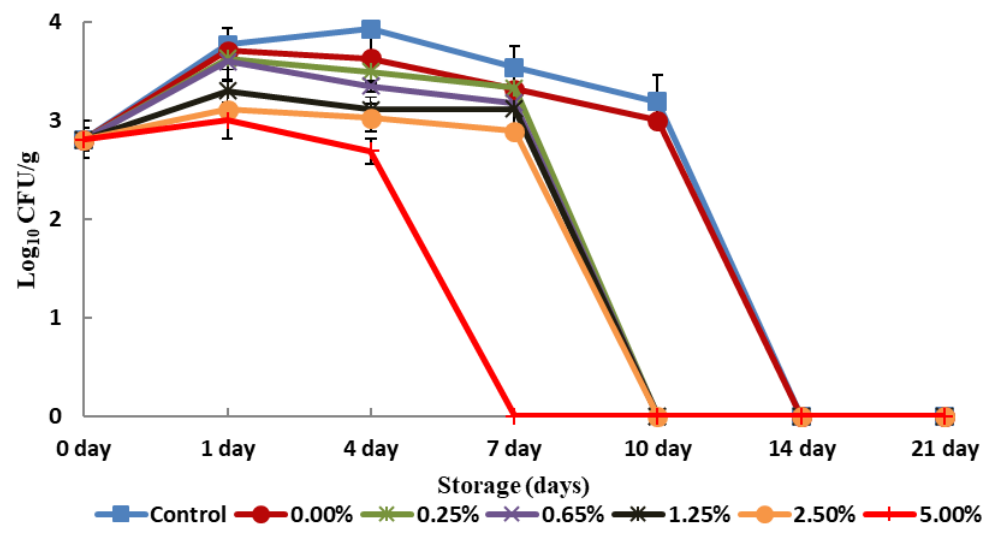

Figure 4. Effect of $M$. fragrans Houtt. extract treatment with concentration of $0.00 \%$ (DW, distilled water), $0.25 \%, 0.65 \%$, $1.25 \%, 2.50 \%$ and $5.00 \%$ on L. monocytogenes on beef during storage at $4 \pm 2^{\circ} \mathrm{C}$ (a) and $-18 \pm 2{ }^{\circ} \mathrm{C}$ (b). Control was untreated raw beef sample. 
$1.25 \%$ extract, coliform was inhibited by the $4^{\text {th }}$ day, whereas treatment with $0.65 \%, 0.25 \%, 0.00 \%$ and control inhibited the growth of coliform after the $7^{\text {th }}$ day. These differences between the antimicrobial activity at different storage temperatures suggest that the antimicrobial activity of the nutmeg extract was enhanced at the lower temperature of $-18^{\circ} \mathrm{C}$.

Figure 3a shows the $\log _{10} \mathrm{CFU} / \mathrm{g}$ reduction of $E$. coli in beef stored at $4.0^{\circ} \mathrm{C}$, which was reduced to undetectable limits with the treatment of $1.25 \%, 2.50 \%$ and $5.00 \%$ extract by the $4^{\text {th }}$ day. In contrast, the lower concentration extracts were not as effective, with $0.65 \%$ inhibiting $E$. coli growth by the $7^{\text {th }}$ day, whereas $0.25 \%$ and $0.00 \%$ had no inhibitory effects on the growth of $E$. coli. The effects of different concentrations and exposure time of M. fragrans Houtt. extract on E. coli in beef stored at $-18^{\circ} \mathrm{C}$ are shown in Figure $3 \mathrm{~b}$, showing that treatment with $1.25 \%, 2.50 \%$ and $5.00 \%$ extracts inhibited $E$. coli growth by the $4^{\text {th }}$ day, with $0.65 \%$ and $0.25 \%$ extracts inhibiting $E$. coli growth by the $7^{\text {th }}$ day and $10^{\text {th }}$ day, respectively. Taken together, these results demonstrated that the increasing concentration of nutmeg extract and the storage at $-18^{\circ} \mathrm{C}$ enhanced the inhibition of E. coli.

Figure 4a shows the effect of nutmeg extract on $L$. monocytogenes in treated beef stored at $4^{\circ} \mathrm{C}$, showing that there was no growth inhibition activity until $10^{\text {th }}$ day, which may be due to the adaptation of the microbe itself as well as the biological adaptations of the active compound in the nutmeg. The unstable phase of microbial growth is attributed to microbial adaptation to the changing conditions, such as chill temperatures and surface desiccation (Raftari et al., 2009). The pattern of logarithmic growth occurs after the microorganism accommodates to a new environmental setting and their metabolism. Treatment with $1.25 \%$ extract and above exhibited the highest antimicrobial activity by the $10^{\text {th }}$ day of storage, while $0.65 \%$ and $0.25 \%$ extract inhibited bacterial growth by the $14^{\text {th }}$ day (Figure $4 a$ ).

The L. monocytogenes growth count of treated beef stored at $-18^{\circ} \mathrm{C}$ is shown in Figure $4 \mathrm{~b}$, indicating that all treatments inhibited L. monocytogenes growth. The $5.00 \%$ extract was most effective, showing inhibitory effects by the $7^{\text {th }}$ day, followed by treatment with $2.50 \%$, $1.25 \%, 0.65 \%$, and $0.25 \%$ extracts showing inhibitory effects by the $10^{\text {th }}$ day, whereas control samples and treatment $0.00 \%$ extract showed microbial inhibition on the $14^{\text {th }}$ day. These findings indicate that higher concentrations of extract can inhibit the growth of $L$. monocytogenes at low temperature storage conditions.

In summary, these results showed the concentrationdependent antimicrobial effects of the nutmeg extract, with a maximal reduction average of $2.66 \log _{10} \mathrm{CFU} / \mathrm{g}$ and minimal reduction of $0.28 \log _{10} \mathrm{CFU} / \mathrm{g}$ of total bacterial count in beef in the samples treated with $5.00 \%$ and $0.25 \%$ M. fragrans Houtt. extract, respectively. In general, treatment with $1.25 \%$ extract showed significant antimicrobial activity $(\mathrm{P}<0.05)$ against all tested microorganisms.

The antimicrobial activity of nutmeg extracts mainly depends on their constituents, with inhibitory action being more related to the major than the minor active compounds. It has been demonstrated that several components are involved in the fixation on cell walls and cellular membrane. Significant antimicrobials and antioxidants have been reported in nutmeg seeds extracts including $\alpha$-pinene, $\beta$-pinene, $p$-cymene, carvacrol, and $\beta$ -caryophyllene (Ogunwande et al., 2003; Dorman et al., 2004), oestrogenic activities, spasmolytic activity (Olajinde et al., 1999), and inhibitory activity of membrane functions by localisation to membranes (Panizzi et al., 2002). The generated volatile compounds by microorganisms during refrigerated storage of the meat at $4^{\circ} \mathrm{C}$ are a significant source of undesirable odours that are considered as an indication of shelf-life expiration. Therefore, it is crucial to reduce or inhibit microbial growth to prevent rancid odours, since it is an indicator of the freshness or the spoilage of the beef (Lee and Shin, 2019).

\section{Conclusion}

Nutmeg (M. fragrans Houtt.) extract exhibited antibacterial activity against selected foodborne pathogens including B. cereus, B. subtilis, E. coli, K. pneumoniae, $L$. monocytogenes, $P$. aeruginosa, $P$. mirabilis and $S$. aureus. In general, the antibacterial activity of the nutmeg extract was not affected by heating or changes in $\mathrm{pH}$. Furthermore, $1.25 \%$ nutmeg extract exhibited antibacterial activity on beef during storage at $4^{\circ} \mathrm{C}$ and $-18^{\circ} \mathrm{C}$, suggesting that $M$. fragrans Houtt.) extract could be used as a natural preservative in beef.

\section{Acknowledgements}

This work was supported by Geran Putra IPS to Yaya Rukayadi Project Number GP-IPS/2013/9396700.

\section{References}

Ababutain, I.M. (2011). Antimicrobial activity of ethanolic extracts from some medicinal plant. Australian Journal of Basic and Applied Science, 5 (11), 678-683.

Acheson, D.W.K. (2003). Emerging Foodborne Enteric Pathogens. In Caballero, B., Trugo, L.C. and 
Fingalas P.M. (Eds.). Encyclopedia of Food Sciences and Nutrition, p. 2062-2069: London: Academic. https://doi.org/10.1016/B0-12-227055-X/00399-0

Andrews, J.M. (2001). Determination of minimum inhibitory concentrations. Journal of Antimicrobial Chemotherapy, 48(suppl_1), 5-16. https:// doi.org/10.1093/jac/48.suppl_1.5

Annalisa, L. Cristina, C., Amalina, C. and Matteo, A.D.N. (2012). Food applications of natural antimicrobial compounds. Frontiers in Microbiology, 3, 287. https://doi.org/10.3389/ fmicb.2012.00287

Ashish, D.G, Vipin, K.B., Vikash, B. and Nishi, M. (2013). Chemistry, antioxidant and antimicrobial potential of nutmeg (Myristica Fragrans Houtt.) Journal of Genetic Engineering and Biotechnology, 11(1), 25-31. https://doi.org/10.1016/ j.jgeb.2012.12.001

Bin, S., Cai, Yi-Z., Brooks, J.D. and Corke, H. (2007). The in vitro antibacterial activity of dietary spice and medicinal herb extracts. International Journal of Food Microbiology, 117(1), 112-119. https:// doi.org/10.1016/j.jifoodmicro.2007.03.003

Chatterjee, S., Niaz, Z., Gautam, S., Adhikari, P.S., Variyar, A. and Sharma. (2007). Isolation and antifungal activity of lignans from Myristica fragrans. Food Chemistry, 101(2), 515-523. https:// doi.org/10.1016/j.foodchem.2006.02.008

Chung, J.Y., Choo, J.H., Lee, M.H. and Hwang, J.K. (2006). Anticarcinogenic activity of macelignan isolated from Myristica fragrans (nutmeg) against Streptococcus mutans. Phyomedicine, 13(4), 261266. https://doi.org/10.1016/j.phymed.2004.04.007

CLSI. (Clinical and Laboratory Standards Institute). (2012). Reference method for dilution antimicrobial susceptibility tests. Approved standard M7- A6 (CLSI). National Committee for Clinical Laboratory Standards, Wayne, PA, USA.

Culter, H.G. (1995). Natural product flavor compounds as potential antimicrobials, insecticides and medicinal. Agro-Food-Industry-Hi-Tech, 6, 19.

Davidson, P.M. and Taylor, M.T. (2007). Chemical preservatives and natural antimicrobial compounds. In Doyle, M.P., Beuchat, L.R. and Montville, T.J. (Eds). Food Microbiology: Fundamentals and Frontiers., p. 520-556. Washington, DC: American Society for Microbiology Press.

Dillon, Y.M. (1994). Natural Antimicrobial Systems and Food Preservation., p. 167-179. CAB International, Oxon.

Doyle, M.E. (2005). Food Antimicrobials, Cleaners, and Sanitizers. A review of the scientific literature.
Retrieved on January 30, 2019 from Food Research Institute, University of Wisconsin Website: http:// fri.wisc.edu/docs/pdf/

Antimicrob_Clean_Sanit_05.pdf.

Dorman, H.J.D., Figueriredo, A.C, Barroso, J.G. and Deans, S.G. (2000). In vitro evaluation of antioxidant activity of essential oils and their components. Flavour Fragrance Journal, 15(1), 1216. https://doi.org/10.1002/(SICI)1099-1026 (200001/02)15:1<12::AID-FFJ858>3.0.CO;2-V

El Malti, J., Bourhim, N. and Amarouch, H. (2008). Toxicity and antibacterial effect of Myristica fragrans in Moroccan gastronomy: Biochemical and histological. Impact Journal of Food Safety, 28(3), 422-441. https://doi.org/10.1111/j.17454565.2008.00110.x

Erasto, P., Bojase-Moleta, G. and Majinda, R.R. (2004). Antimicrobial and antioxidant flavonoids from the root wood of Bolusanthus speciosus. Phytochemistry, 65(7), 875-880. https:// doi.org/10.1016/j.phytochem.2004.02.011

Gangoué-Piéboji, J., Eze, N., Djintchui, A.N., Ngameni, B., Tsabang, N., Pegnyemb, D.E., Biyiti, L., Ngassam, P., Koulla-Shiro, S. and Galleni, M. (2009). The in-vitro antimicrobial activity of some medicinal plants against $\beta$-lactam-resistant bacteria. The Journal of Infection in Developing Countries, 3, 671-680. https://doi.org/10.3855/ jidc.77

Janssens, J. Laekeman, G.M., Pieters, L.A.C., Totte, J, Herman, A.G. and Vlietinck, A.J. (1990). Nutmeg oil: Identification and quantitation of its most active constituents as inhibitors of platelet aggregation. Journal of Ethnopharmacology, 29(2), 179-188. https://doi.org/10.1016/0378-8741(90)90054-W

Jeremiah, L.E. and Gibson, L.L. (2001). The influence of storage temperature and storage time on color stability, retail properties and case-life retail ready beef. Food Research International, 34(9), 815-826. https://doi.org/10.1016/S0963-9969(01)00104-1

Kwon, H.S., Kim, Min-Jung, Jeong, H.Y., Yang, M.S., Park, K.H., Jeong, T. and Lee, W.S. (2008). Lowdensity lipoprotein (LDL) -antioxidant lignans from Myristica fragrans seeds. Bioorganic and Medicinal Chemistry Letters, 18(1), 194-198. https:// doi.org/10.1016/j.bmcl.2007.10.098

Lambert, P.A. (2002). Cellular impermeability and uptake of biocides and antibiotics in Gram-positive bacteria and mycobacteria. Journal of Applied Microbiology, 92(s1), 46S-54S. https:// doi.org/10.1046/j.1365-2672.92.5s1.7.x

Lee, E.J. and Shin, H.S. (2019). Development of a 
freshness indicator for monitoring the quality of beef during storage. Food Science and Biotechnology, 18. https://doi.org/10.1007/s10068-019-00633-5

Ogunwande, A.I., Olawore, N.O., Adeleke, A.K. and Konig, A.W. (2003). Chemical composition of the essential oils the leaves of three Eucalyptus species growing in Nigeria. Journal of Essential Oil Research, 15(5), 297-301. https:// doi.org/10.1080/10412905.2003.9698595

Olajinde, O.A., Ajayi, F.F., Ekhelar, A.L., Awe, S.O., Makinde, J.M. and Alanda, A.R.A. (1999). Biological effects of Myristica fragrans (nutmeg) extract. Phytotherapy Research, 13(4), 344-345. https://doi.org/10.1002/(SICI)1099-1573(199906) 13:4<344::AID-PTR436>3.0.CO;2-E

Patal, S.D. and Kamble, V.E. (2011). Antibacterial activity of some essential oils against some food born pathogen and food spoilage bacteria. International Journal of Pharma and Bio Sciences, 2 (3), 143-150.

Panizzi, L., Caponi, C., Catalano, S., Cioni, P.L. and Morelli, I. (2002). In vitro antimicrobial activity of extracts and isolated constituents of Rubus ulmifolius. Journal of Ethnopharmacology, 79(2), 165-168. https://doi.org/10.1016/S0378-8741(01) 00363-4

Raftari, B. (2009). Application of he's hormotopy perturbation method and variational iteration method for nonlinear partial integro differential quations. World Applied Science Journal, 7(4), 399-404.

Rukayadi, Y., Shim, J.S. and Hwang, J.K. (2008). Screening of Thai medicinal plants for anticandidal activity. Mycoses, 51(4), 308-312. https:// doi.org/10.1111/j.1439-0507.2008.01497.x

Souza, E.L.D., Stamford, T.L.M., Lima, E.D.O., Trajano, V.N. and Barbosa Filho, J.M. (2005). Antimicrobial effectiveness of spices: an approach for use in food conservation systems. Brazilian Archives of Biology and Technology, 48(4), 549-558. https:// doi.org/10.1590/S1516-89132005000500007

Takikawa, A., Abe, Y., Yamamoto, M., Ishimaru, S., Yasui, M., Okubu, Y. and Yokoigawa, K. (2002). Antimicrobial activity of nutmeg against Escherichia coli O157. Journal Bioscience Bioengineering, 94 (4), 315-320. https://doi.org/10.1016/S1389-1723 (02) $80170-0$

Velasco, V. and Williams, P. (2011). Improving meat quality through natural antioxidants. Chilean Journal of Agricultural Research, 71(2), $313 . \quad$ https:// doi.org/10.4067/S0718-58392011000200017 